\title{
ANALISIS KESULITAN MENYELESAIKAN SOAL MATEMATIKA MATERI OPERASI HITUNG BILANGAN PECAHAN SISWA KELAS VII
}

\author{
Novita Karina Dewi ${ }^{1)}$ \\ Zainuddin Untu $^{2)}$ \\ Ariantje Dimpudus ${ }^{3)}$ \\ 1), 2), 3) Pendidikan Matematika FKIP Universitas Mulawarman

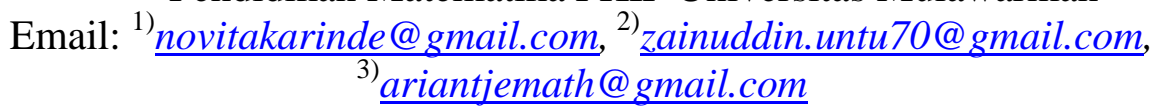

\begin{abstract}
ABSTRAK
Penelitian ini merupakan penelitian deskriptif kualitatif dengan tujuan untuk mengetahui dan mendeskripsikan kesulitan-kesulitan siswa dalam menyelesaikan soal matematika materi operasi hitung bilangan pecahan. Subjek dalam penelitian ini adalah siswa kelas VII yang berjumlah 68 siswa. Pengumpulan data dilakukan melalui observasi, tes tertulis dan wawancara. Data yang terkumpul dianalisis berdasarkan tahapan mentranskrip data, memberi kode, mereduksi data, menyajikan data dan membuat kesimpulan. Hasil penelitian menunjukkan indikasi siswa yang mengalami kesulitan diantaranya, siswa tidak dapat memahami penjelasan dari guru, saat mengerjakan soal siswa tampak gelisah dan jawaban beberapa siswa yang acak-acakan serta coretan atau tulisan tidak jelas dan tidak terarah, meskipun jawabannya mendekati benar. Dari hasil analisis, disimpulkan kesulitan-kesulitan siswa dalam menyelesaikan soal materi operasi hitung bilangan pecahan yaitu kesulitan dalam menggunakan konsep, kesulitan dalam menggunakan prinsip dan kesulitan dalam menyelesaikan masalah-masalah verbal. Temuan lainnya, diketahui bahwa siswa yang memiliki nilai diatas kriteria ketuntasan minimal (KKM) juga mengalami kesulitan dalam menyelesaikan soal matematika materi operasi hitung bilangan pecahan.
\end{abstract}

Kata kunci: Kesulitan, Menyelesaikan Soal, Matematika.

\begin{abstract}
This research is qualitative descriptive that aims for known and described the type of students' difficulties in solving mathematical problems on fraction number operations. Subjects in this study were students of class VII with total of 68 students. Data collected by observation, test and interview. Data analysis through several stages of transcribing data, coding, reducing data, data presentation and making conclusions. The results showed the indication of difficulties in solving mathematical problems experienced by students are, students can't understand explanation by the teacher, when students working on the test they seem nervous and their answers on the worksheet are messy with some undescribe text although the answers are almost correct. The conclusion from analyisis, the type of students' difficulties in solving mathematical problems of fraction number operations are, difficulties in using concepts, difficulties in using principles, difficulties in solving the verbal problems. The other result showed, the students who have score above minimum criteria of mastery
\end{abstract}


learning experienced the difficulties in solving mathematical problems of fraction number operations too.

Keywords: Difficulties, Problem Solving, Mathematics.

\section{PENDAHULUAN}

Pendidikan adalah usaha sadar dan terencana untuk mewujudkan suasana belajar dan proses pembelajaran agar siswa secara aktif mengembangkan potensi dirinya untuk memiliki kepribadian, kecerdasan, akhlak mulia, serta keterampilan yang diperlukan dirinya, masyarakat, bangsa dan negara. Oleh karena itu, pendidikan sebagai wadah bagi siswa dalam mengembangkan kemampuan dan potensi dirinya, perlu diikuti dengan kualitas pendidikan yang baik, agar siswa menjadi sumber daya manusia (SDM) yang berkualitas baik pula. Upaya meningkatkan kualitas pendidikan dan sumber daya manusia dengan program wajib belajar 12 tahun wajib dilakukan oleh setiap warga negara. Dalam pelaksaannya, siswa diwajibkan menempuh mata pelajaran wajib, salah satunya adalah pelajaran matematika.

Pelajaran matematika merupakan salah satu mata pelajaran yang dalam proses pembelajarannya membutuhkan tingkat pemahaman yang lebih, karena matematika tidak hanya sebatas persoalan hitung menghitung dan bukan hanya hapalan, tetapi cakupannya jauh lebih luas dari presepsi kebanyakan orang selama ini. Paling (dalam Abdurrahman, 2012:203) mengemukakan bahwa, matematika adalah suatu cara untuk menemukan jawaban terhadap masalah yang dihadapi manusia; suatu cara menggunakan informasi, pengetahuan tentang bentuk dan ukuran, tentang menghitung dan yang paling penting adalah memikirkan dalam diri manusia itu sendiri.

Pembelajaran matematika di sekolah tidak hanya dimaksudkan untuk mencapai tujuan yang bersifat material, yakni untuk membekali siswa agar menguasai matematika dan menerapkannya dalam kehidupan sehari-hari, akan tetapi lebih dari itu, pembelajaran matematika juga dimaksudkan untuk mencapai tujuan yang bersifat formal, yaitu untuk membentuk kepribadian dan menata nalar siswa agar mampu memecahkan masalah. Yeni (dalam Kumalasari, Ade dan Sugiman, 2015:1) menjelaskan hal ini sangat memerlukan keuletan dan ke-tekunan, sehingga matematika sering di-anggap sebagai ilmu yang sulit untuk di-pahami karena abstrak bagi siswa tingkat sekolah dasar bahkan hingga mahasiswa di perguruan tinggi

Kesulitan siswa dalam memahami matematika sudah sering terdengar dan hingga saat ini matematika masih menjadi momok yang serius bagi sebagian masyarakat. Terkait dengan pernyataan ini, Hoyles (dalam Kumalasari, Ade dan Sugiman, 2015:2) menjelaskan bahwa beberapa siswa memandang matematika sebagai subjek yang menyebabkan ketakutan, kecemasan dan kemarahan selama pelajaran. Sedangkan Abdurrahman (2012:202) mengemukakan bahwa dari berbagai bidang studi yang diajarkan disekolah, matematika merupakan bidang studi yang dianggap paling sulit dipahami 
oleh para siswa, terlebih bagi siswa yang berkesulitan belajar. Kesulitan belajar matematika yang dialami oleh para siswa akan menyebabkan siswa semakin tidak berminat mempelajari matematika dan jika melihat bagaimana pentingnya matematika dalam kehidupan sehari-hari, maka dapat diprediksi bahwa siswa akan mengalami kesulitan dalam kehidupan sosialnya apabila tidak memahami matematika dengan baik.

Selama praobservasi penulis menemukan bahwa jumlah waktu pembelajaran untuk pelajaran matematika kurang berdasarkan Permendikbud No. 22 Tahun 2016, durasi 1 jam pelajaran untuk SMP yaitu 40 menit sedangkan dilapangan hanya berdurasi 35 per jam pelajaran. Berdasarkan hasil wawancara dengan guru matematika di SMP Budi Luhur Samarinda diperoleh informasi diantaranya adalah siswa sering mengalami kecemasan atau keraguan di dalam menyelesaikan soal-soal matematika pada materi yang telah diajarkan dan masih banyak siswa yang mengalami kesulitan dalam memahami dan menyelesaikan soal-soal operasi hitung bilangan pecahan. Meskipun, ada siswa yang memperoleh nilai diatas kriteria ketuntasan minimal (KKM) pada ulangan harian materi operasi hitung bilangan pecahan, nilai yang diperoleh tidak lebih dari 78 .

Jamaris (2014:3) mengemukakan bahwa kesulitan adalah suatu kelainan yang membuat individu yang bersangkutan sulit untuk melakukan kegiatan secara efektif. Sedangkan Ismail (2016:33) mengemukakan bahwa kesulitan dapat diartikan suatu kondisi tertentu yang ditandai dengan ada- nya hambatan-hambatan dalam mencapai tujuan, sehingga memerlukan usaha lebih giat lagi untuk dapat mengatasi. Kesulitan adalah suatu kondisi yang ditandai dengan adanya hambatan-hambatan pada individu dalam mencapai tujuan, dengan tingkat dan jenis sumber kesulitan yang beragam bagi individu yang besangkutan.

Mulyadi (2010:6) mengemukakan bahwa kesulitan belajar dapat diartikan sebagai suatu kondisi dalam suatu proses belajar yang ditandai adanya hambatanhambatan tertentu untuk mencapai hasil belajar. Menurut Westwood (dalam Kumalasari, Ade dan Sugiman, 2015:18) kesulitan belajar mengacu pada hambatan yang membatasi akses partisipasi dan hasil dalam sebuah rencana pembelajaran. Lebih lanjut, Rumini (dalam Irham \& Wiyani, 2016:254) memandang kesulitan belajar merupakan kondisi dimana peserta didik mengalami hambatan-hambatan tertentu dalam mengikuti proses pembelajaran untuk mencapai hasil belajar secara optimal. Dalyono (2012:229) mengartikan kesulitan belajar merupakan suatu keadaan yang menyebabkan siswa tidak dapat belajar sebagaimana mestinya. Menurut Partowisastro dan Hadisuparto (dalam Suwarto, 2017:88) siswa mengalami kesulitan belajar jika tidak dapat memenuhi harapan yang diisyaratkan kepadanya oleh sekolah. Dari beberapa pendapat diatas memiliki kesamaan tentang kesulitan belajar yaitu hambatan-hambatan dalam belajar. Jadi, dapat disimpulkan bahwa kesulitan belajar adalah hambatanhambatan tertentu yang dialami oleh siswa dalam proses pembelajaran sehingga siswa tidak dapat belajar dengan semestinya serta 
tidak tercapainya hasil belajar yang diharapkan.

Menurut Dalyono (2012:247-248) terdapat beberapa gejala-gejala pada siswa yang mengalami kesulitan belajar, yaitu:

1. Menunjukkan prestasi belajar yang rendah/ dibawah rata-rata yang dicapai kelompok kelas.

2. Hasil yang dicapai tidak seimbang dengan usaha yang dilakukan. Ia berusaha dengan keras tetapi nilainya selalu rendah.

3. Lambat dalam mengerjakan tugas yang diberikan oleh gurunya.

4. Menunjukkan sikap yang kurang wajar seperti acuh tak acuh, membuat gaduh dan lain sebagainya.

5. Menunjukkan tingkah laku yang berlainan, seperti murung, mudah tersinggung pemarahan dan lain sebagainya.

Menurut Kereh, Sabadar dan Tjiang (2013:11) mengemukakan bahwa kesulitan belajar matematika dapat terjadi pada hampir setiap tahap/jenjang selama masa sekolah siswa, bahkan pada orang dewasa (mahasiswa). Kesulitan belajar matematika menurut Lerner (dalam Abdurrahman, 2012:210) disebut juga diskalkulia (dyscalculis). Istilah diskalkulia memiliki konotasi medis, yang memandang adanya keterkaitan dengan gangguan sistem saraf pusat. Kesulitan belajar matematika yang berat menurut Kirk (dalam Mulyadi, 2010:178) disebut akalkulia (acaculia). Sedangkan gangguan matematika menurut Mulyadi (2010:178) adalah suatu ketidakmampuan dalam melakukan keterampilan matematika yang diharapkan untuk kapasitas intelektual dan tingkat pendidikan seseorang. Berdasarkan pendapat para ahli di atas, dapat disimpulkan kesulitan belajar matematika adalah suatu ketidakmampuan dalam melakukan keterampilan matematika yang diharapkan untuk kapasitas intelektual dan tingkat pendidikan seseorang karena adanya keterkaitan dengan gangguan sistem saraf pusat.

Kesulitan menyelesaikan soal matematika sebagai gangguan pada satu atau lebih proses dasar psikologis dalam me-mahami atau menggunakan bahasa tulis, yang akan tampak dalam menyelesaikan hitungan matematika (Aunurrahman, 2014:187). Selanjutnya, Abrar (dalam Jamaris, 2014:61) mengemukakan bahwa kesulitan siswa dalam menyelesaikan matematika dapat dilihat dari siswa menjawab/ memecahkan masalah matematika. kesulitan siswa dalam menyelesaikan soal matematika yaitu gangguan dalam memahami atau menggunakan bahasa tulis, yang akan tampak dari hasil tulisan siswa dalam menjawab masalah matematika atau menyelesaikan hitungan matematika.

Cooney, Davis, dan Henderson (dalam Yusmin, 2017:2123) mengelompokkan kesulitan menyelesaikan soal matematika ke dalam tiga jenis kesulitan, yaitu:

1. Kesulitan menggunakan konsep

Kriteria siswa mengalami kesulitan menggunakan konsep matematika dalam menyelesaikan soal terdiri dari :

a. Ketidakmampuan mengingat namanama secara teknis.

b. Ketidakmampuan menyatakan arti dari istilah yang mewakili konsep tertentu.

c. Ketidakmampuan mengingat satu atau 
atau lebih kondisi yang diperlukan oleh suatu objek untuk dinyatakan dengan istilah yang mewakilinya.

d. Ketidakmampuan mengingat suatu kondisi yang cukup dari suatu objek untuk dinyatakan dengan istilah yang mewakili konsep tersebut.

e. Tidak dapat mengelompokkan objek yang merupakan contoh atau bukan contoh dari suatu konsep yang dibahas.

f. Ketidakmampuan menyimpulkan informasi dari suatu konsep yang diberikan.

2. Kesulitan menggunakan prinsip

Kriteria siswa kesulitan menerapkan prinsip dalam menyelesaikan soal meliputi :

a. Ketidakmampuan siswa melakukan kegiatan penemuan tentang sesuatu yang karena tidak teliti melakukan perhitungan atau operasi hitung.

b. Ketidakmampuan siswa untuk menentukan faktor yang relevan dan akibatnya tidak mampu mengabstraksikan pola-pola.

c. Siswa dapat menyatakan suatu prinsip tetapi tidak dapat mengutarakan artinya, dan tidak dapat menerapkan prinsip tersebut.

3. Kesulitan menyelesaikan masalahmasalah verbal.

Soegiono (dalam Paridjo, 2008:7) menyatakan bahwa kesulitan-kesulitan siswa dalam menyelesaikan masalah verbal meliputi kesulitan dan ketidakmampuan siswa dalam :

a. menggunakan data.

b. mengartikan bahasa.

c. menarik kesimpulan.

Pembelajaran matematika adalah akti- vitas proses belajar mengajar dengan adanya interaksi antar siswa dengan guru atau antar siswa dalam menyampaikan dan menerima ilmu pengetahuan baru sebagai upaya meningkatkan penguasaan yang baik terhadap materi matematika.

Bilangan pecahan merupakan bagian dari keseluruhan dan dinyatakan dalam bentuk $\frac{\mathrm{a}}{\mathrm{b}}$ yang mana $\boldsymbol{a}$ dan $\boldsymbol{b}$ adalah bilangan-bilangan bulat dimana $b \neq 0$ dan $b$ bukan faktor dari $a$. Operasi hitung pada pecahan adalah pengerjaan hitung pada pecahan. Dalam hal ini maksudnya ialah penjumlahan, pengurangan, perkalian dan pembagian.

\section{METODE PENELITIAN}

Penelitian ini menggunakan metode penelitian deskriptif kualitatif. Metode deskriptif kualitatif yaitu suatu metode penelitian yang digunakan untuk menemukan pengetahuan terhadap subjek penelitian pada suatu saat tertentu dengan mendeskripsikan seluruh gejala atau keadaan yang ada (Mukhtar, 2013:10-11). Penelitian dilakukan dengan rmaksud untuk memperoleh informasi dan mengetahui gambaran tentang jenis kesulitan siswa dalam menyelesaikan soal yang berkaitan dengan operasi hitung bilangan pecahan. Hasil dari pengumpulan data, direduksi dan dideskripsikan, dan selanjutnya disajikan kedalam kategori jenis-jenis kesulitan siswa dalam menyelesaikan soal, kemudian dibuat kesimpulannya.

Penelitian ini dilaksanakan pada tanggal 15 Agustus 2019 hingga 7 September 2019 di SMP Budi Luhur Samarinda. Subjek penelitian adalah siswa kelas VII sebanyak 68 orang. Sedangkan 
yang menjadi objek penelitian adalah kesulitan menyelesaikan soal matematika yang dialami siswa, yang dalam penelitian ini jenis-jenis kesulitan siswa dianalisis berdasarkan pendapat Cooney, et. Al. yakni kesulitan menggunakan konsep, kesulitan menggunakan prinsip dan kesulitan menyelesaikan masalah-masalah verbal pada materi operasi hitung bilangan pecahan.

Pengumpulan data dalam penelitian ini dilakukan melalui observasi, tes terulis, dan wawancara serta dokumentasi. Secara rinci diuraikan sebagai berikut.

\section{Observasi}

Observasi dalam penelitian ini merupakan observasi partisipasi pasif. Dalam hal ini, peneliti melakukan pengamatan terhadap kegiatan pembelajaran matematika materi operasi hitung bilangan pecahan. Kegiatan observasi dilakukan pada setiap kegiatan pembelajaran sejak pembukaan sampai penutupan kegiatan pembelajaran tentang materi operasi hitung bilangan pecahan dengan menggunakan pedoman/format/ lembar pengamatan.

2. Tes

Tes dalam penelitian ini merupakan tes tertulis berbentuk soal uraian yang terdiri dari 6 butir yang terkait dengan materi operasi hitung bilangan pecahan. Sebelum tes ini diberikan dan diujikan kepada siswa, terlebih dahulu divalidasi oleh ahli/pakar (validator).

Pelaksanaan tes ini dilakukan dengan tujuan untuk memperoleh respon siswa sebagai subjek penelitian dalam menyelesaikan soal matematika materi operasi hitung bilangan pecahan, tergolong kedalam kategori jenis kesulitan sesuai dengan indikator jenis kesulitan siswa berdasarkan pendapat Cooney et al. Penulis menggunakan indikator jenis kesulitan siswa berdasarkan pendapat Cooney et al tersebut sebagai dasar penentuan indikasi yang dialami oleh siswa. Pemberian kode pada hasil tes siswa dengan nomor dan kode huruf, berdasarkan tabel 1. Misal, siswa tidak menyelesaikan hasil perhitungannya, maka diberi kode " $2 b$ ". Berikut ini tabel indikator kesulitan siswa dalam mengerjakan soal menurut Cooney et al yang penulis modifikasi dari Yusmin.

3. Wawancara

Kegiatan wawancara ini dilakukan dengan tujuan untuk mendapatkan informasi dan gambaran yang lebih jelas dan lengkap tentang kesulitan yang dialami siswa. Wawancara ini dilakukan terhadap

Tabel 1. Indikator Kesulitan dalam Menyelesaikan Soal

\begin{tabular}{llll}
\hline No. Jenis Kesulitan & \multicolumn{3}{l}{ Indikator } \\
\hline $\begin{array}{l}\text { 1. } \\
\text { Kesulitan dalam } \\
\text { menggunakan }\end{array}$ & a. & $\begin{array}{l}\text { Siswa tidak tepat dalam menerjemahkan bentuk/ilustrasi dari soal. } \\
\text { konsep }\end{array}$ & $\begin{array}{l}\text { Siswa tidak tepat dalam menggunakan rumus yang sesuai dengan } \\
\text { kondisi prasyarat berlakunya rumus. }\end{array}$ \\
\hline $\begin{array}{l}\text { Kesulitan dalam } \\
\text { menggunakan } \\
\text { prinsip }\end{array}$ & $\begin{array}{l}\text { a. } \\
\text { b. }\end{array}$ & $\begin{array}{l}\text { Siswa tidak tepat dalam menggunakan sifat-sifat operasi hitung. } \\
\text { Siswa tidak menyelesaikan perhitungan. }\end{array}$ \\
\hline $\begin{array}{l}\text { Kesulitan dalam } \\
\text { menyelesaikan }\end{array}$ & a. & Siswa tidak tepat dalam menerjemahkan kedalam model \\
masalah-masalah & b. & Siswa tidak tepat dalam menggunakan data yang akan digunakan \\
& verbal & c. & Siswa tidak tepat dalam menarik kesimpulan. \\
& & & (Sumber : Modifikasi Yusmin 2017)
\end{tabular}


guru mata pelajaran dan siswa (subjek) yang terindikasi mengalami kesulitan dalam menyelesaikan soal matematika yang diberikan dengan menggunakan pedoman wawancara. Sebelum pedoman wawancara ini digunakan terlebih dahulu dikonsultasikan kepada pakar dan divalidasi oleh dua orang ahli. Adapun wawancara yang dilakukan yang dilakukan dalam penelitian ini merupakan wawancara tidak terstruktur. Adapun subjek yang dipilih sebagai responden dalam kegiatan wawancara yaitu subjek yang paling banyak menunjukkan indikasi mengalami kesulitan dalam menyelesaikan soal tes tertulis materi operasi hitung bilangan pecahan. Hal ini dilakukan, untuk memperoleh konfirmasi dan menggali informasi jenis-jenis kesulitan yang dialami subjek. Dalam penelitian ini terdapat 8 subjek yang memenuhi kriteria sebagai responden yang diwawancarai (Tabel 3).

\section{Dokumentasi}

Dokumentasi adalah kumpulan datadata pendukung yang diperoleh selama proses penelitian sebagai penguat dan pelengkap data hasil observasi dan data hasil wawancara. Sebagai sumber data yang dijadikan sebagai dokumentasi dalam penelitian ini yaitu semua data hasil pekerjaan/jawaban atau respon siswa terhadap tes yang memuat 6 butir soal matematika bentuk uraian tentang operasi hitung bilangan pecahan. Adapaun data dokumentasi yang lebih diperhatikan yaitu data respon siswa atau subjek yang terindikasi mengalami kesulitan berdasarkan indikator jenis kesulitan yang dikemukakan oleh Cooney et al.

\section{HASIL PENELITIAN DAN PEMBA- HASAN}

Indikasi siswa mengalami kesulitan tampak dari hasil observasi yang telah dideskripsikan sebelumnya, yaitu saat pembelajaran siswa kurang memahami materi yang diajarkan secara jelas dan sistematis oleh gurunya. Dari hasil jawaban siswa terhadap tes yang diberikan diperoleh bahwa dari 68 siswa yang diuji, beberapa siswa dapat mengalami lebih dari satu jenis kesulitan pada hampir setiap nomor soal. Maka, kesulitan-kesulitan siswa yang dapat dikategorikan kedalam jenis-jenis kesulitan siswa dalam menyelesaikan soal-soal matematika materi operasi hitung bilangan pecahan sebagai berikut yakni kesulitan dalam menggunakan konsep sebanyak 25 siswa, kesulitan dalam menggunakan prinsip sebanyak 69 siswa dan kesulitan dalam menyelesaikan masalah-masalah verbal sebanyak 10 siswa. Jumlah siswa (subjek) yang terindikasi kesulitan pada setiap butir soal disajikan dalam Tabel 2.

Tabel 2. Jumlah Subjek yang Terindikasi Mengalami Kesulitan di Setiap Soal

\begin{tabular}{ccccc}
\hline \multirow{2}{*}{$\begin{array}{c}\text { No. } \\
\text { Soal }\end{array}$} & \multicolumn{3}{c}{ Banyak Subjek } & J \\
\cline { 2 - 4 } & $\mathbf{K}$ & $\mathbf{P}$ & $\mathbf{V}$ & \\
\hline 1 & 8 & 10 & 3 & 21 \\
2 & 5 & 10 & 1 & 16 \\
3 & 5 & 16 & 1 & 22 \\
4 & 2 & 14 & 0 & 16 \\
5 & 2 & 9 & 4 & 15 \\
6 & 3 & 10 & 1 & 14 \\
\hline Jumlah & 25 & 69 & 10 & 104 \\
\hline$\%$ & $24,04 \%$ & $66,35 \%$ & $9,61 \%$ & $100 \%$ \\
\hline (Sumb
\end{tabular}

(Sumber : Data Hasil Penelitian 2019)

Ket :

K : Kesulitan dalam Konsep

P : Kesulitan dalam Prinsip

V : Kesulitan dalam Masalah Verbal 
Berdasarkan Tabel 2,

1) Kesulitan dalam menggunakan konsep yang dialami siswa yaitu sebesar 24,04\%. Jumlah seluruh siswa yang kesulitan dalam menggunakan konsep dari 6 butir soal yang diberikan adalah sebanyak 25 siswa dan terbanyak ditemui pada butir soal nomor 1 yakni sebanyak 8 siswa.

2) Kesulitan dalam menggunakan prinsip yang dialami siswa yaitu sebesar $66,35 \%$. Jumlah seluruh siswa yang kesulitan dalam menggunakan prinsip dari 6 butir soal yang diberikan adalah sebanyak 69 siswa dan terbanyak ditemui pada butir soal nomor 3 yakni sebanyak 16 siswa.

3) Kesulitan dalam menyelesaikan masalah verbal yang dialami siswa adalah sebesar 9,61\%. Jumlah seluruh siswa yang kesulitan dalam menyelesaikan masalahmasalah verbal dari 6 butir soal yang diberikan adalah sebanyak 10 siswa dan terbanyak ditemui pada butir soal nomor 5 yakni sebanyak 4 siswa.

Berdasarkan hasil pekerjaan/jawaban siswa dalam menyelesaikan soal tentang materi operasi hitung bilangan pecahan diperoleh bahwa, dari tiga indikator jenis kesulitan yang dikemukakan oleh Conney et al, kesulitan menggunakan prinsip merupakan kesulitan yang paling menonjol dialami siswa. Adapaun hasil pekerjaan/jawaban dan respon dari 8 subjek yang merupakan responden dalam penelitian ini, yang dikategorikan berdasakan jenis-jenis kesulitan yang dialaminya dan yang terindikasi pada setiap butir soal beserta hasil tes tertulisnya adalah seperti yang terlihat pada Tabel 3 .

Tabel 3. Indikasi Kesulitan Pada Setiap Nomor Soal beserta Hasil Tes dari Responden

\begin{tabular}{|c|c|c|c|c|c|c|c|c|c|c|c|c|c|c|c|c|c|c|c|}
\hline \multirow{2}{*}{$\mathbf{R}$} & \multicolumn{3}{|c|}{ Soal No. 1} & \multicolumn{3}{|c|}{ Soal No. 2} & \multicolumn{3}{|c|}{ Soal No. 3} & \multicolumn{3}{|c|}{ Soal No. 4} & \multicolumn{3}{|c|}{ Soal No. 5} & \multicolumn{3}{|c|}{ Soal No. 6} & \multirow{2}{*}{$\mathbf{N}$} \\
\hline & $\mathbf{K}$ & $\mathbf{P}$ & $\mathbf{V}$ & $\mathbf{K}$ & $\mathbf{P}$ & $\mathbf{V}$ & $\mathbf{K}$ & $\mathbf{P}$ & $\mathbf{V}$ & $\mathbf{K}$ & $\mathbf{P}$ & $\mathbf{V}$ & $\mathbf{K}$ & $\mathbf{P}$ & $\mathbf{V}$ & $\mathbf{K}$ & $\mathbf{P}$ & $\mathbf{V}$ & \\
\hline C-17 RNF & & $\checkmark$ & $\checkmark$ & & $\checkmark$ & $\checkmark$ & & $\checkmark$ & & & $\checkmark$ & & & $\checkmark$ & & & $\checkmark$ & & 84 \\
\hline A-33 ZAS & & $\checkmark$ & & & $\checkmark$ & & & & & & $\checkmark$ & & & & & & $\checkmark$ & & 83 \\
\hline A-21 MFN & & & & & & & & & & & $\checkmark$ & & & & $\checkmark$ & & $\checkmark$ & $\checkmark$ & 80 \\
\hline A-15 JSN & & & & $\checkmark$ & $\checkmark$ & & & & & & & & & $\checkmark$ & & $\checkmark$ & $\checkmark$ & & 52 \\
\hline B-08 GNR & $\checkmark$ & $\checkmark$ & & & $\checkmark$ & & & $\checkmark$ & & & $\checkmark$ & & & $\checkmark$ & & & $\checkmark$ & & 51 \\
\hline B-16 MYP & & $\checkmark$ & & & & & $\checkmark$ & $\checkmark$ & & $\checkmark$ & $\checkmark$ & & & & & & & & 47 \\
\hline B-01 AIA & & & & & & & & $\checkmark$ & $\checkmark$ & $\checkmark$ & $\checkmark$ & & & $\checkmark$ & & & $\checkmark$ & & 35 \\
\hline C-07 HJA & $\checkmark$ & & & $\checkmark$ & $\checkmark$ & & & & & & & & $\checkmark$ & $\checkmark$ & $\checkmark$ & & & & 34 \\
\hline
\end{tabular}

(Sumber : Data Hasil Penelitian 2019)

Ket :

$\mathbf{R}:$ Responden

$\mathbf{N}$ : Nilai Tes Responden

Tabel 3 menunjukkan bahwa, setiap responden terindikasi mengalami kesulitan yang berbeda-beda pada setiap butir soal dan memperoleh skor nilai yang bervariasi. Namun demikian terdapat 3 responden yang terindikasi paling banyak mengalami kesulitan dalam menyelesaikan soal matematika materi operasi hitung bilangan 
pecahan tetapi ketiganya juga memperoleh skor nilai paling tinggi di atas nilai kriteria ketuntasan minimal (KKM) sekolah 70 yakni responden RNF dengan skor nilai 84 , ZAS dengan skor nilai 83, dan responden MFN dengan skor nilai 80 .

Hasil penelitian ini sesuai dengan hasil triangulasi bersama guru matematikanya yang menunjukkan bahwa, semua indikasi kesulitan siswa dalam menyelesaikan soal yang diberikan dan yang terjadi saat menyelesaikan soal-soal latihan di kelas, hasil wawancara serta hasil observasi, tampak tidak ada perbedaan dengan keterangan yang disampaikan oleh guru matematka dan sesuai pengalaman guru tersebut selama dalam membelajarkan matematika di kelas. Di samping itu, dari hasil keabsahan penelitian ini dijelaskan bahwa, dari hasil ulangan harian siswa tentang materi operasi hitung bilangan pecahan ini, terindikasi siswa mengalami kesulitan. Hal ini dikonfirmasi saat wawancara dengan responden salah satunya yaitu responden mengalami kebingungan seperti saat menentukan model matematika dari soal atau lupa rumus yang digunakan sehingga ragu saat melanjutkan ke operasi hitung.

Berdasarkan penelitian yang telah dilakukan ini, peneliti menemukan jenisjenis kesulitan yang dialami siswa dalam menyelesaikan soal matematika materi operasi hitung bilangan pecahan di kelas VII SMP Budi Luhur Samarinda antara lain kesulitan dalam menggunakan konsep, kesulitan dalam menggunakan prinsip dan kesulitan dalam menyelesaikan masalahmasalah verbal.

Kesulitan siswa dalam menggunakan konsep adalah ketidakmampuan untuk mengingat nama-nama secara teknis dan ketidakmampuan mengingat suatu kondisi yang cukup bagi suatu objek untuk dinyatakan dengan istilah yang mewakili konsep tersebut serta ketidakmampuan untuk menyatakan arti dari istilah yang mewakili konsep tertentu, seperti siswa lupa dalam menentukan nilai pembilang dan nilai penyebut dari sebuah ilustrasi pecahan sejenis, sebagai contoh menyamakan penyebut dari operasi hitung pecahan tak sejenis tetapi tidak mengubah pembilangnya.

Selanjutnya, yang termasuk jenis kesulitan dalam menggunakan prinsip yaitu tidak mampu melakukan kegiatan penemuan tentang sesuatu yang tidak teliti dalam perhitungan atau operasi hitung dan ketidakmampuan siswa untuk menentukan faktor yang relevan dan akibatnya tidak mampu mengabstraksikan pola-pola, seperti siswa sering kali kurang teliti dalam menuliskan algoritma perhitungan atau kurang tepat dalam menuliskan algoritmanya, seperti tidak menyelesaikan perhitungan, ragu dalam menentukan sifat operasi hitung terutama pada soal yang memiliki banyak operasi hitung dan mengalami kesusahan dalam menyederhakan hasil pecahan.

Kesulitan siswa dalam menyelesaikan masalah-masalah verbal yaitu siswa tidak memahami istilah-istilah khusus seperti siswa sering kurang teliti dalam memasukkan data yang sesuai kebingungan dan kurang teliti seperti dalam membuat kedalam model matematikanya.

Salah satu gejala kesulitan siswa menurut Dalyono (2012:247-248) yaitu siswa menunjukkan prestasi belajar yang rendah atau dibawah rata-rata yang dicapai 
kelompok kelas, hal ini tidak sejalan dengan hasil dari yang peneliti temukan dalam penelitian ini. Pada penelitian ini, terindikasi bahwa siswa yang memiliki prestasi yang cukup tinggi atau siswa memiliki nilai diatas kriteria ketuntasan minimal (KKM), juga mengalami kesulitan dalam menyelesaikan soal materi operasi hitung bilangan pecahan.

\section{KESIMPULAN}

Berdasarkan hasil penelitian dan pembahasan maka disimpulkan bahwa, kesulitan-kesulitan menyelesaikan soal materi operasi hitung bilangan pecahan yang dialami siswa kelas VII di SMP Budi Luhur Samarinda terdiri dari kesulitan menggunakan konsep, prinsip, dan kesulitan menyelesaikan masalah verbal Kesulitan menggunakan prinsip merupakan kesulitan yang paling banyak dialami siswa dalam menyelesaikan soal matematika materi operasi hitung bilangan pecahan. Kesulitan dalam menyelesaikan soal materi operasi hitung bilangan pecahan ini tidak hanya dialami oleh siswa yang memperoleh skor nilai dibawah kriteria ketuntasan minimal (KKM) akan tetapi lebih banyak dialami oleh siswa yang memperoleh skor nilai jauh di atas KKM.

\section{DAFTAR PUSTAKA}

Abdurrahman, M. (2012). Anak Berkesulitan Belajar: Teori, Diagnosis dan Remediasinya. Rineka Cipta.

Aunurrahman. (2014). Belajar dan Pembelajaran. Alfabeta.

Dalyono, M. (2012). Psikologi Pendidikan. Rineka Cipta.
Irham, M. dan Wiyani, N.A.. (2016). Psikologi Pendidikan Teori dan Aplikasi dalam Proses Pembelajaran. Ar-Ruzz Media.

Ismail. (2016). Diagnosis Kesulitan Belajar Siswa dalam Pembelajaran Aktif di Sekolah. Jurnal Edukasi. 2(1):33.

Jamaris, M. (2014). Kesulitan Belajar. Ghalia Indonesia.

Kereh, C. T., Sabadar, J., dan Tjiang, P. C. (2013). Identifikasi Kesulitan Belajar Mahasiswa dalam Konten Matematika pada Materi Pendahuluan Fisika Inti. Proceedings of Seminar Nasional Sains dan Pendidikan Sains VIII, Fakultas Sains dan Matematika, UKSW Salatiga. 4(1): 11-12

Kumalasari, Ade, dan Sugiman. (2015). Analisis Kesulitan Belajar Mahasiswa Pada Mata Kuliah Kapita Selekta Matematika Sekolah Menengah. Jurnal Riset Pendidikan Matematika. 2(1):17-18

Mukhtar. (2013). Metode Praktis Penelitian Deskriptif Kualitatif. Referensi

Mulyadi. (2010). Diagnosis Kesulitan Belajar dan Bimbingan Terhadap Kesulitan Belajar Khusus. Nuha Litera.

Paridjo. (2008). Suatu Solusi Mengatasi Kesulitan Belajar Matematika. Universitas Terbuka.

Suwarto. (2017). Pengembangan Tes Diagnostik dalam Pembelajaran. Pustaka Pelajar

Yusmin, E. (2017). Kesulitan Belajar Siswa Pada Pelajaran Matematika (Rangkuman dengan Pendekatan Meta-Ethnogrphy). Jurnal Visi Ilmu Pendidikan. 9(1):2123 